\title{
Mobile Money as a Strategy for Financial Inclusion in Rural Communities
}

\author{
Mr. Thulani \\ Dube,University of Kwazulu-Natal, South Africa \\ Prof. Pepukayi Chitakunye
}

University of the Witwatersrand, South Africa

\section{Dr. Bibi Zaheenah Chummun}

University of Kwazulu-Natal, South Africa

Doi:10.5901/mjss.2014.v5n25p216

\section{Abstract}

This study contributes to a deeper understanding of the usage level of mobile money, and how it has accelerated financial inclusion among the rural communities in an emerging economy such as Zimbabwe. The study employed a mixed methods approach and a concurrent dominant status design where quantitative and qualitative approaches were concurrently used with the quantitative approach having a dominant status. The study was carried out in the Midlands Province and a simple random sampling technique was applied to select the province. Eight districts in the province formed the study population of 262493 households and a pilot sample size of 37 household was chosen. The study used a survey method to collect data, where a questionnaire and focus group discussions were used as the main data collection instruments. It emerged that the usage of mobile money by the unbanked rural people is very high, especially for sending and receiving remittances. However the saving and loan aspect of mobile money were not very popular. Users were still relying on their traditional methods of savings and borrowing. The implications are that the service providers need to increase their awareness programs targeting this specific market to encourage them to migrate from traditional ways to safe and secure way of saving their meagre income. More so, that their saving patterns will determine their access to loans.

Keywords: mobile money, financial inclusion, remittances, savings, Zimbabwe.

\section{Introduction}

The development and deployment of mobile money has generated a lot of interest among stakeholders, particularly in developing countries to solve infrastructural gaps that hinder an all inclusive financial system (Dermish, Kneiding, Leishman \& Mas, 2012). The traditional banking service has targeted the affluent consumers who reside in the urban locations neglecting the larger marginalized consumers residing in rural areas (Hinson, 2011).

Within this context, the challenges cited by banks have been the cost of physical infrastructure, operational cost and unprofitability of serving these consumers given the levels of their disposable income (Boston Consulting Group, 2011; Goss, Mas, Radcliffe \& Stark, 2011; Mas, 2010; Mas, 2012;Alleman \& Rappoport, 2010; Alexandre, Mas \& Radcliffe, 2011; Dermish, Kneiding, Leishman \& Mas, 2012). The expansion of network coverage by Mobile Network Operators (MNO) and the penetration of mobile phones throughout Zimbabwe has circumvented the infrastructural barriers, that is, in developing countries mobile phone network counteract poor infrastructure and geographical isolation that contribute high cost of providing banking services to the rural communities (Oluwatayo, 2013; De Sousa, 2010; Alexandre, Mas, \&Radcliffe, 2011; Jack \& Suri, 2011 and Flores-Rouxy \& Mariscal, 2011).

In sub- Saharan Africa, $75 \%$ of the population do not have access to any form of formal financial services (Mas, 2010; Alexandre, Mas \& Radcliffe, 2011) while in Zimbabwe, 70\% of the country's population live in the rural areas and only $11.7 \%$ of the branch network serve them (Reserve Bank of Zimbabwe, 2007 and World Bank, 2012). This implies that people from the rural communities still travel long distances to the nearest bank to get financial services, denuding or exhausting their very limited disposable income. Generally, the country has low banking levels in terms of branch outreach compared with regional banking levels, for example South Africa 63\%, Namibia 62\%, Swaziland 44\% and in Zimbabwe $24 \%$ of the population is banked (FinMark Trust, 2011). The $76 \%$ unbanked population is too significant to 
ignore. Therefore, it is important that these consumers are included in the official economy versus the black market economy and this is only possible through modern forms of monetary technology.

It is envisioned that mobile banking will provide access to finance and market opportunities for the previously disadvantaged communities consequently leading poverty reduction (Dolan, 2009; Kasseeah \& Tandrayen-Ragoobur, 2012; International Finance Corporation, 2012). Zimbabwean banks and mobile network operators have made efforts to exploit the need by launching different kinds of mobile money services. Some of the products and services that have been launched are shown in the table below:

Table 1: Mobile Money Deployments in Zimbabwe

\begin{tabular}{|c|c|}
\hline Institution & Mobile Product \\
\hline Econet Wireless & EcoCash \\
\hline Kingdom Bank & Cellcard \\
\hline Tetrad & eMali \\
\hline CABS & Textacash \\
\hline Interfin Bank & Cybercash \\
\hline NetOne & One Wallet \\
\hline Telecel & TeleCash \\
\hline FBC & Mobile Moola \\
\hline
\end{tabular}

Source: Kufandirimbwa, Zanamwe, Hapanyengwi \& Kabanda (2013: 93)

Of the above listed products, it is the Econet Wireless' Ecocash that has captured the limelight and registered an estimated 2 million subscribers to their mobile money (Kufandirimbwa et al, 2013). It is the fastest growing mobile money after the Kenyan M-Pesa. Therefore, the aim of this study is to determine how the development of technology enabled inclusion has increased accessibility and improved the livelihood of the rural communities in Zimbabwe.

\section{Literature Review}

Anyasi \& Otubu (2009) and Davids (2012) defined mobile money as a range of financial services accessible to consumers through mobile phone devices. The common functions include balance checks, depositing and withdrawing cash (cash-in and cash -out), funds transfer, savings, access credit, long distance remittances, bill payments and airtime purchase (Donner and Tellez, 2008; Kasseeah \& Tandrayen-Ragoobur, 2012; Jenkins, 2008). On assessing alternative banking services Kumbhar (2011) called the functions service fulfillment and systems availability quantitative indicators that explain how many types of services are available thereby indicating the usage level of the service. Qualitatively the inclusiveness of the financial system can be evaluated the basis of the following indicators: risk minimization, speed of service, ease of use, innovativeness, cost effectiveness, responsiveness, customer education and credit counseling, (Kumbhar, 2011). However, Donner and Tellez (2008) note that there is no universally agreed type of mobile money, however structure varies from one country to another. Mobile money technology offers the potential for millions of people living in emerging markets that have access to the mobile phone, yet remain excluded from the financial mainstream (Ismail \& Masinge, 2011). They represent potential for growth of banks and telecom service providers as well as rural people to save and access financial services (Infosys, 2009).

On the other hand, financial inclusion is defined as the provision of financial services to the excluded and disadvantaged groups at an affordable cost (Kuar, 2013). Chibba (2009) underscored the importance of financial inclusion as a means of addressing poverty and issues of access and equity. The goals of financial inclusion include ensuring access to basic financial services by all, promoting economic growth, social and economic empowerment, breaking cycles of poverty and inculcating the savings culture in rural areas to foster realization of Millennium Development Goals (MDGs) (RBZ, 2007). The mobile banking facility enhances financial inclusion for the rural people as it overcomes the barriers faced by traditional banks.

A large population in most, if not all developing countries does not have access to a bank and these have been classified as 'unbanked', 'under banked', or 'unbankable' (Kasseeah \&Tandrayen-Ragoobur, 2012; Griffin, 2013). Interestingly McNaughton (nd) argues that the microfinance industry has demonstrated that the extreme poor are extremely bankable. Therefore mobile money platforms can be an important tool for the financial inclusion of people without bank accounts and limited access to formal banking service in developing countries especially in Africa. The 
deployment of mobile banking offers potential for facilitating trade among transacting parties in goods and financial services (Kasseeah \& Tandrayen-Ragoobur, 2012). In Africa the most successful launched mobile banking facility has been M-Pesa in Kenya with over 14 million registered users and it is the best example of a mobile money service for the financially excluded (IFC, 2012; Wooder \& Baker, 2012). In the developed world, for example USA and European countries, mobile money penetration is insignificant due to the alternative electronic payment systems which are well developed. However, Japan is considered the most successful mobile money developed country and has the highest penetration levels in the world (IFC, 2012; Merrit,2011; Au \& Kauffman, 2007, Porteous, 2006).

\subsection{Impact of Mobile Money}

Duncombe and Boateng (2009) noted that there were few studies so far conducted on the impact assessment of mobile money due to the fact that many such innovations were still at their adolescent stages of implementation. Kumbhar (2011) identified important indicators which can be applied in the assessment of alternative banking services as means of financial inclusion. The indicators were broadly categorized as qualitative, quantitative and impact indicators, where impact indicators included change in income, change in savings, change in living standards, the level of indebtedness, and the level of banking habits. Furthermore, a review of empirical studies revealed positive impact on savings, information exchange, increased income and remittances and reduced costs (Dermish et al,2012; Morawczynski, 2011; Jack \& Suri, 2011 and Morawczynski, Demombynes \& Thegeya, 2012, Mbiti \& Weil, 2011).

\subsubsection{Improved communication and information exchange}

The use of mobile phone serves a dual purpose, that is, as a communication medium as well as for banking. Mobile communication networks enable information to move freely, enabling markets to be more efficient thereby unleashing entrepreneurship and consequently leading to financial innovation that allows mobile phones to be used as gateways to financial access by the previously unbanked rural communities. There are also relational benefits that accrue between transacting parties eliminating the need for middlemen, as a result it shrinks information asymmetry and increases the frequency of transactions and redress market inefficiencies (Hinson, 2011; Bhavhani et al, 2008; Dermish et al, 2012; Abraham, 2006). In that respect this study examines how the use of mobile money has contributed to the livelihood of rural communities in Zimbabwe.

\subsubsection{Reduced Costs}

Costs refers to the cost savings and operational efficiency which a customer or firm may accrue as a result of adoption of technology (Boardi et al, 2007). Transaction costs are the costs related to using the system for example costs associated to sending and receiving money (Boateng, 2011). Mas and Radcliffe (2010) noted that mobile banking turns fixed costs into variable costs but enough to allow the agent to promote the service alongside other products. Bhavhani et al (2008) demonstrated the effects of using mobile money in the improvement in information flow between transacting parties allowing efficiency among the trading without travelling. This was noted particularly for users in rural areas where traders would have needed to travel to urban areas to send and receive money. Hence, mobile money usage results in the reduction in transportation cost and consequently increased consumer surplus (Sife et al, 2010).

\subsubsection{Savings}

Mobile money serves as a phone-cum savings account, thus enabling people without a formal bank account to engage in a safer and more efficient savings mechanism. It actually improves efficiency and regularity of savings (Nandhi, 2012). It has banking has a transformational benefit offering something new, that is, new ways to access services and support livelihood (Boateng, 2011; Heeks \& Jagun, 2007; Morawczynski \&Pickens, 2009; Alleman \& Rappoport, 2010; Radcliffe \& Voorhies, 2012). Morawczynski(2011) revealed that incomes for rural mobile money users increased due to remittances which also led to higher savings. Demombynes and Thegeya (2012) demonstrated the possibility of mobile money increasing savings while Jack and Suri (2011) assert that mobile money users saved to store funds safe from dangers of theft and inaccessibility to other family members. They further postulate that savings have the potential of adding social value to those constrained by cost opening a bank account and large distance between their household and the closest formal savings establishment (Jack \& Suri, 2011). 


\subsubsection{Improved Remittance}

Mobile money service allows users/customers to benefit from remittances from either family members or friends living abroad. This alone, assuming all other factors remain constant, will results in improved economic well being as the poor will get a source of income (Hinson, 201; Morawczynski \&Pickens, 2009; Alleman \& Rappoport, 20101). Maguna, Bailey and Cliffe (2009) assert that interdisciplinary research has focused on the contribution remittances make to economic development. Morawczynski, Demombynes and Thegeya (2012) noted that the use of mobile money increased money circulation boosting local consumption for the rural people spurning economic activity. They further assert that the flow of remittances to rural areas increase economic activity by enabling "just-in-time" transfers that make capital available whenever it is needed.

\section{Research Methodology}

The study was carried out in Zimbabwe in the Midlands Province and a simple random sampling technique was applied to select the Midlands Province. A list of the ten provinces was drawn and the names were put on a container and then the province was chosen. Midlands Province is one of the ten geopolitical zones in Zimbabwe. It is a region located in the central part of the country and where diverse ethnic groups reside. The province is divided into fourteen census districts from South to North (Mberengwa, Zvishavane, Zvishavane Mine, Shurugwi, Shurugwi Rural, Chirumanzi, Gweru, Gweru Rural, Redcliff, Kwekwe, Kwekwe Rural, Gokwe South, Gokwe Town and Gokwe North). For this study only eight rural districts formed the population and sampling frame. The province's major economic activities include mining, farming and cattle ranching to a lesser degree. Table 2 below shows the number of households per district.

Table 2: Number of households be district

\begin{tabular}{|c|c|c|c|c|c|}
\hline Code & District & No of Household & Code & District & No of Household \\
\hline 701 & Chirumnazi & 19736 & 705 & Kwekwe Rural & 38107 \\
\hline 702 & Gokwe North & 49584 & 706 & Mberengwa & 38852 \\
\hline 703 & Gokwe South & 63224 & 707 & Shurugwi Rural & 17134 \\
\hline 704 & Gweru Rural & 20756 & 708 & Zvishavane & 15100 \\
\hline & & & & Total & $\mathbf{2 6 2 4 9 3}$ \\
\hline
\end{tabular}

Source: ZIMSTATS (2012: 90)

\subsection{Sampling Procedure and Data Collection}

A multistage cluster sampling technique was used in selecting the household. The sample was drawn in four stages as follows:

i. Selection of study districts. The first stage involved a random selection of one district out of eight districts in the Midlands Province. The population size in each district is shown in table 1. A list of the eight districts forming the study population was drawn and the names were put in a container. Using simple random sampling technique, Kwekwe Rural district was chosen.

ii. Sampling of the Ward. A list of the wards from the chosen district was drawn and the ward numbers were put in a container. Using simple random sampling technique, two wards were chosen.

iii. Sampling of Villages. A sampling frame of villages was compiled, where a list of the villages were obtained from chief in the ward. The number of villages per ward ranged between 8 and 12 villages. The village names were put in a container and using simple random sampling, a village was chosen per ward. Therefore two villages were chosen from the two wards.

iv. Sampling of households. This was the last stage where the sampling units for the survey were the households with the mobile phone and the respondent was the household head because in rural setup most livelihood assets tend to be owned at household level. Purposive sampling technique was used to select members of the focus group discussion (FGD). In each ward at least eight household heads were chosen to participate in the focus group discussion. 


\subsection{Research Instruments}

The study used a survey method to gather primary data, where the questionnaire and focus group discussions were the main instrument for data collection. The questionnaire measures were adapted from previous literature for example, Ismail \& Masinge, 2011; Sife et al, 2010; Gross, Hogarth \& Schmeiser, 2012 and Kumbhar, 2011. Likert type questions were used because the measured constructs on the impact of mobile money on livelihood is quite broad and contain multiple aspects that cannot easily be measured with single items. Participants in the focus group discussions were purposively selected based on their socioeconomic characteristics and experience in using the mobile money services. Each focus group discussion was composed of ten members. Two focus group discussions were conducted for this study, with four major themes usage, remittances, savings and loan.

\section{Data Analysis}

\subsection{Respondent Profile}

The profile of household heads (respondents) are shown in table 3 below, where the majority of them were males (59.6\%), married (73\%), employed (54.1\%) with secondary education (54.1\%) and a mean age of 30.5 years.

Table 3: Respondent Profile

\begin{tabular}{|ccc|}
\hline Demographic Profile & N & Percentage \\
Gender & & \\
Female & 15 & 40.5 \\
Male & 22 & 59.6 \\
Total & 37 & $100 \%$ \\
AGE & & \\
16-25 years & 2 & 5.4 \\
26-35 years & 13 & 35.1 \\
36-45 years & 9 & 24.3 \\
46-55 years & 4 & 10.9 \\
>55 years & 9 & 24.3 \\
Total & 37 & $100 \%$ \\
MARITAL & & \\
Married & 27 & 73 \\
Divorced & 2 & 5.4 \\
Widowed & 3 & 8.1 \\
Single & 5 & 13.5 \\
Total & 37 & $100 \%$ \\
EDUCATION & & \\
Primary & 8 & 21.6 \\
Secondary & 20 & 54.1 \\
Tertiary & 9 & 24.3 \\
Total & 37 & $100 \%$ \\
OcCUPATION & & \\
Employed & 20 & 54.1 \\
Unemployed & 7 & 18.9 \\
Self-employed & 10 & 27 \\
Total & 37 & \\
\hline
\end{tabular}

Two focus group discussion were conducted and the group membership was diverse as it was composed of different groups (between 26-65 years, both male and female members, banked and the unbanked) to stimulate debate and capture different perspectives on the usage and impact of mobile money as financial inclusion strategy for rural communities. The group members included farmers, teachers, pensioners, vendors, small scale miners (makorokoza) and the unemployed, that is, the group members were drawn from various income generating activities. The focus group discussions were scheduled for one hour though ended up exceeding the agreed time due to enthusiasm in the debate.

Exploratory factor analysis was used to explore the grouping of variables to seek underlying patterns for the questionnaire survey. In order to discover similar and significant clusters of issues of variables, principal component 
analysis (PCA) with Varimax rotation and Kaiser Normalisation were conducted. Eigen values equal to 0.4 or greater than 0.4 were extracted with the regards to fifteen variables used yielding three factors accounting for $55.8 \%$ (first factor), $17.4 \%$ (second factor) and $8 \%$ of the total (81.2\%) variance explained. Only variables with factor loadings greater than 0.5 were selected for inclusion and the factors are mobile money service fulfillment with 7 items, mobile money savings with 3 items and remittances with just 3 item.

The suitability of the data for factor analysis was determined by examining the Kaiser-Meyer-Olkin (KMO) measure of sampling adequacy and the Bartlett test of sphericity. The KMO measure was 0.834 which is greater than 0.6 and is regarded as meritorious for factor analysis while the Bartlett test is statistically significant $(0.000)$. The statistics indicate that the data is safe for factor analysis. The amount of variance explained by each item was shown with good fit as most items had variance explained were greater 0.3 . The reliability of the instrument was assessed using Cronbach's alpha coefficient with a score of 0.874 which is above the 0.7 threshold which shows that the instrument is reliable. The statistics indicated that the data is suitable for factorization.

\subsection{Mobile money usage}

Table 4 below shows the usage of mobile money service by the respondents, where deposit, withdrawals (cash-in and cash-out), fund transfers and airtime purchase had highest means. This is an indication of high usage of the service fulfillment, while bill payment, savings and loans were not frequently used.

Table 4: MMS Usage and Impact

\begin{tabular}{|l|c|c|c|c|c|}
\hline & $\mathrm{N}$ & Minimum & Maximum & Mean & Std. Deviation \\
\hline Purchase Airtime & 37 & 1 & 5 & 4.19 & 1.525 \\
Bill payment & 37 & 1 & 5 & 2.11 & 1.646 \\
Deposit/ Withdrawal & 37 & 4 & 5 & 4.62 & .492 \\
Funds Transfer & 37 & 1 & 5 & 4.41 & 1.117 \\
Savings & 37 & 1 & 5 & 2.30 & 1.762 \\
Loan & 37 & 1 & 2 & 1.11 & .315 \\
MMS Allows speedy transfer of funds (Q27) & 37 & 1 & 5 & 4.35 & .857 \\
PIN Enhances Security of funds (Q33) & 37 & 1 & 5 & 4.14 & .918 \\
MMS Reduces Lose of funds (Q34) & 37 & 1 & 5 & 4.08 & .894 \\
Service & 37 & 2 & 5 & 4.35 & .753 \\
Accessibility (Q41) & & & & & \\
MMs has increased & 37 & 1 & 5 & 3.97 & 1.213 \\
Incomes (Q42) & & & & & \\
Valid N (listwise) & & & & & \\
\hline
\end{tabular}

Similarly, results of focused group discussion (FGDs) indicated that respondents had used the mobile money service fulfillment, the most to be used were the funds transfer (receiving remittances) and airtime purchase. The group members indicated that mobile money had increased their access to financial services as most of the members travel under $10 \mathrm{~km}$ to access the nearest mobile money agent. On the frequency of use the results indicated that they used the service several times a week to several times a month with the employed using it more frequent. The members opined that with the advent of mobile money (Ecocash) sending and receiving money had become cheap, fast and ease.

Moyo: "Now am able to send money directly to my sister in Harare and then buys me replenishment stock for my business."

MaSibanda: "Occassionally at the end of the month my son sends me money through ecocash. He works in Harare".

Dendere: "It is the same with me, when I have an emergency I notify my children who work in towns and they send me money through ecocash".

They highlighted how challenging it used to be to get their family members or friends send them money especially the elderly with children working in distant cities like Harare and Bulawayo. They concurred that the formal ways of sending money were secure but costly while informal channels (e.g. bus driver) were insecure hence mobile money became a perfect substitute. 


\title{
4.3 Mobile money and Income
}

Group members pointed out that there was a general increase on the remittances from the family members or friends abroad. However the group members who were employed differed in opinion as they indicated that there was no change in their income as result of using mobile money other than being a convenient way of funds transfer. Pensioners like the other members noted how the mobile money service had cut transport costs as they were able to transfer their incomes from the bank to mobile (Ecocash) account.

\begin{abstract}
Mavumba: "Ecocash has helped me to cut on transport costs I used to incur going to town to get my pension income from the bank. Now I just transfer cash from the bank to my mobile money wallet."

Ncube: "For me the unemployed, I have been able to receive money through ecocash, there has been some difference even if I get as little as \$2 it makes some difference".
\end{abstract}

Through mobile money micro transfers were possible and the amounts received ranged from $\$ 10-\$ 30$ as disclosed by group discussion members. It was noted that mobile money facilitated transfer of small amounts allowing recipients to attend to emergencies. Small scale minors and vendors added their voice on how mobile money had increased their capital when needed, especially when buying stock funds were quickly transferred to their mobile money account as when they were required.

\subsection{Mobile Money and Savings}

The survey results showed that the savings and loans were still very unpopular with mobile money users as shown in table 4 with means 2.30 and 1.11 respectively and further investigation on purpose of saving the results were consistent, savings through mobile money was unpopular. The results from focus discussions were similar with the questionnaire survey. Using FGDs, the members were quizzed on their financial literacy to reveal their literacy level, the responses where as diverse as the group composition. In general, the members showed that they had little knowledge on formal financial facilities especially as far as savings and credit was concerned. They highlighted that they still relied on their traditional savings method (e.g. under the pillow or mattress) and on emergence they borrowed from friends or family members. It was the young employed group members who showed knowledge on these facilities as offered by banks and not mobile money provider. They indicated that they had received messages on their mobile phones about savings and loan schemes sent by mobile money provider but they did not know how it operated.

Nyoni:"I have received promotional messages on ecosave but ignored them because I did not understand them."

Ncube: "I find it difficult to save because I use ecocash mostly to receive money when I have an emergency".

Dendere: I have not heard about savings facility and if I have enough knowledge I would want to save especially when I have surplus from my deals".

As a storage facility few members indicated that they had kept their money on the Ecocash account for a month as most of them had used mobile money as a transfer mechanism and still kept at home their excess cash.

\subsection{Discussion}

Mobile money service has increased financial access and usage by rural communities and has positive impact on remittances with funds transfer (sending and receiving) outstanding on usage. The findings confirm the findings by Morawczynski \& Pickens (2009), Mas \& Morawczynski (2009) and Mbiti \& Weil (2011). However, contrary to their findings the savings and loan facility had not registered use and pattern changes among the groups interviewed. Though there is likelihood of use if mobile money service providers increased awareness through educational programs as indicated by the interested generated during the discussion. The pilot study demonstrated that there were mixed outcomes on the effect of mobile money on user incomes, however, Mbiti \& Weil (2011) using quantitative approach showed that M-Pesa in Kenya mobile money increased incomes of users. Morawczynski, Demombynes \& Thegeya (2012) and Kumbhar (2011) in a related studies reached similar conclusions. The indifference shown on savings and loans could be due to the fact that these were new product offerings that are hardly a year old whereas funds transfer, deposit and withdrawals (cash-in and cash-out), bill-payments and airtime purchase have been there for over two years hence their popularity. 


\subsection{Conclusion}

Mobile money service has a positive bearing on financial inclusion as evidenced by the access and usage of mobile money by the rural people. It has increased their access to affordable financial services within their locality. Most noteworthy was the positive impact on remittance and reduced costs. The savings and loan facilities were not popular despite being available to these deemed excluded sections of the population.

\subsection{Recommendations}

The study recommends that mobile money providers through bank partnerships carry out an educational program aimed at informing and educating rural people to save through mobile money service. This will help explain the relationship between their savings and loan scheme.

\subsection{Future Research}

The pilot study will generate preliminary results that will contribute advancing research on the impact of mobile money services on rural communities. The findings will be used to further improve on the survey instrument that will be used to gather data related to impact of mobile money services on livelihood of rural people. A Structural Equation Model (SEM) on the impact of mobile money will be developed and tested using Analysis of Moment Structures (AMOS) software. The use of Exploratory Factor Analysis was used to discover the factors that can be refined and used in SEM for this research.

\subsection{Limitations of this Research}

The main limitation of the study was the vernacular language used in focused group discussions. To make the interactions more fluent the participants were allowed to use their vernacular languages which had to be translated to English and this could dilute their points. However, a research assistant was sought to assist in translating.

\section{References}

Abraham, R. (2006). Mobile Phones and Economic Development: Evidence from the Fishing Industry in India, ICTD.

Alexandre, C., Mas, I., \& Radcliffe, D. (2011). Regulating New Banking Models to Bring Financial Services to All, Challnge, Vol. 54( 3).

Alleman, J., \& Rappoport, P. (2010). Mobile Money: Implications for Emerging Markets, Communications \& Strategies, No. 79, $3^{\text {rd }}$ Quarter.

Au, Y., A., \& Kauffman, R., J. (2007). The economics of mobile payments: Understanding stakeholder issues for an emerging financial technology application, Electronic Commerce Research and Application.

Bhatia, D. Bhvanani, A., Chiu, R. W., Janakiram, S., \& Silarszky, P.(2008). The role of Mobile Phones in sustainable Rural Poverty Reduction, ICT Policy Division, Global Information and Communication Departmment (CGICT).

Boardi, R. A., Boateng, R., Hinson, R., \& Epoku, R.(2007). Preliminary insights into M-commerce adoption in Ghana, Information Development, Vol. 23(4), pp 253-265.

Boateng, R. (2011). Mobile phones and micro-trading activities- conceptualising the link, Emerald, Vol. 13(5), 48-62.

Boston Consulting Group (2012). The Socio-economic Impacts of Mobile Financial Services: Analysis of Pakistan, Bangladesh, India, Serbia and Malaysia.

Chibba, M. (2009). Financial Inclusion, Poverty Reduction and the Millennium Development Goals, European Journal of Development Research, Vol. 21(2), 213-230.

Comminos, A., Esselaar, S., Ndiwalana, A., \& Stork, C.(2008). Towards Evidence based ICT Policy and Regulation: M-Banking the Unbanked, Volume 1, Policy Paper 4.

De Sousa, S. (2010). The role of payment systems in reaching the unbanked, Journal of Payment Strategy \& Systems, Vol. 4( 2).

Dermish, A., Kneiding, C., Leishman, P., \& Mas, I. (2012). Branchless and Mobile Banking Solutions for the Poor: A Survey of Literature, Innovations, Vol. 6( 4), 81-98.

Dolan, J. (2009). Accelerating the development of Mobile Money Ecosystem, Washington DC; IFC and the Harvard Kennedy School.

Donner, J., \& Tellez, A. (2008). Mobile banking and economic development: Linking Adoption, impact, and use; Asian Journal of Communication, Vol. 18(4), 318-332.

Duncombe, R., \& Boateng, R. (2009). Mobile Phones and Financial Services in Developing Countries: A Review of Concepts, Methods, Issues, Evidence and Future Research Direction, Development Informatics, Working Paper No 37, Institute for Development Policy and Management, SED.University of Manchester, UK.

Flores-Roux, E., \& Mariscal, J. (2011). The Development of Mobile Money Systems, CIDE, www.cide.edu. 
Goss, S., Mas, I., Radcliffe, D., \& Stark, E. (2011). The Next Challenge: Challenging Savings Through Mobile Money Schemes, World Economic Forum Report, April 2011.

Griffin, H. (2013). Has Mobile Phone Technology had Impact on Quality of Life in the Developing World, Far East Journal of Psychology and Business, Vol. 11(3).

Gross, B. M., Hogarth, M. J., \& Schmeiser, D. M. (2012). Use of Financial Services by the Unbanked and Underbanked and the Potential for Mobile Financial Services Adoption, Federal Reserve Bulletin, Vol. 98(4).

Hannig, A., \& Jansen, S. ( 2010). Financial Inclusion and Stability: Current Policy Issues, ADBI Working Paper Series. No. 259.

Heeks, R., \& Jagun, A. (2007). Mobile phones and development: Future in new hands? Id21 Insights (69). ISSN 1460-4205.

Hinson, E. R. (2011). Banking the Poor, The roles of mobiles, Journal of Financial Services Marketing, Vol.15, pp 320-333. doi:10.1057/fsm.201029.

International Finance Corporation (IFC), Ensuring Financial Inclusion via Mobile Money, Journal of E-Gornance, 2012.

International Telecommunications Union Report. 2012.

Infosys Technologiess (2009). Banking the unbanked: Going Mobile in Africa.

Ismail, T., \& Masinge, K. (2011). Mobile banking: Innovation for the Poor, University of Pretoria, South Africa.

Jenkins, B. (2008). Developing Mobile Money Ecosystems, Washington DC: International Finance (IFC) and the Havard Kennedy School.

Kasseeah, H., \& Tandrayen-Ragoobur, V. (2012). Mobile Money in an Emerging Small Island Economy, ARPN Journal of Science and Technology, Vol. 2(5).

Kufandirimbwa, O., Zanamwe, N., Hapanyengwi, G., \& Kabanda, G. (2013). Mobile Money in Zimbabwe: Integrating Mobile Infrastructure and Processes to Organisation Infrastructure and Processes, Online Journal of Social Science Research, Volume 2(4), 92-110.

Kumbhar, M., V. (2011). A Multinational Concept Instrument (eFI-Test) for Assessment of E-Financial Inclusion. National Conference on Accounting of Social Sector Development, Dpt of Economics, Shivaji University, Kolhapur, India, February 1-2, 2011.

Leech, N., A., \& Onwuegbuzzie, J. A. (2007). A topology of mixed methods research designs, Springer Science + Business Media.

Macharia, J., \& Okunoye, A. (2013). Mobile Banking Influence on wealth Creation for the Unbanked, International conference on ICT for Africa 2013, February 20-23, Harare, Zimbabwe.

Mackenzie, S.B., Podsakoff, P. M., \& Podzakoff, N. P. (2011). Construct measurement and Validation procedures in MIS and Behavioural Research: Integrating new and existing techniques. MIS Quaterly, Vol. 35(2), 293-334.

Magunha, F., Bailey, A., \& Cliffe, L. (2009). Remittance Strategies of Zimbabweans in North England.

Marumbwa, J., \& Mutsikiwa, M. (2013). An analysis of the factors influencing consumers' adoption of Mobile Money Transfer services in Masvingo Urban, Zimbabwe. British Journal of Economics Management \& Trade, Vol. 3(4), 498 - 512.

Mas, I. (2009). The Economics of Branchless Banking, Journal of Innovations, Technology, Governance and Globalisation, Vol. 4(2).

Mas, I. (2010). Banking for the Poor, INTERNATIONAL ECONOMY, Fall, 2010.

Mas, I. (2010). Savings for the Poor, Banking on Mobile Phones, WORLD ECONOMY, Vol. 11(4).

Mas, I. (2012). Transforming Access to Finance in Developing Countries through Mobile Phones: Creating an Enabling Policy Framework, Banking \& Finance, Law Review, Vol. 27(2), 285-298.

Mas, I., \& Radcliffe, D. (2011). Scaling Mobile Money, Journal of Payment Strategy \& Systems, Vol. 5(3) 298-315.

Medhi, I., Ratan, A., \& Toyama, K.. (nd). Mobile-Banking Adoption and Usage by Low-Literate, Low-Income Users in the Developing World, Microsoft Research, India.

Merritt, C. (2011). Mobile money transfer services: The next phase in the evolution of person-to-Person payments, Journal of Payments Strategy \& Systems, Vol. 5(2).

Morawczynski, O., \& Pickens, M. (2009). Poor People Using Mobile Financial Services: Observation on Customer Usage and Impact from M-Pesa, CGAP

Nandhi, M., A. (2012). Effects of mobile banking on the savings practices of the low-income users: The Indian Experience, Institute for Money, Technology \& Financial Inclusion (IMTFI), WORKING PAPER NO 7, Jesus and Mary College, University of Dehli, India.

Porteous, D. (2006). The Enabling Environment For Mobile Banking in Africa, Department of International Development (DFID), UK.

Oluwataya, I. (2013). Banking the unbanked in rural Southwest Nigeria: Showcasing mobile phones as mobile banks among farming households, Journal of Financial Services Marketing Vol. 18, 65-73.

Radcliffe, D., \& Voorhies, R. (2012). A Digital Pathway to Financial Inclusion.

Sife, S., A., Kiondo, E., \& Lyimo-Macha, G. J. (2010). Contributions of Mobile Phones To Rural Livelihoods and Poverty Reduction in Mororgoro Region, Tanzania, Electronic Journal of Information Systems in Developing Countries (EJISDC), Volume 42(3), 1-15.

Wooder, S., \& Baker, S. (2012). Extracting Key Lesson in Service Innovation, Journal of Product Development and Innovation Management, Vol. 29(1).

FinMark Trust (2011). Fin Scope Consumer Survey.

Reserve Bank of Zimbabwe (2007). Expanding Outreach of Established Developmental Institutions. 